\title{
Preliminary Studies on the Protecting Possibilities of Selected Small Water Bodies in the Area of Krakow Agglomeration*
}

\section{Introduction}

Over the last decades a constant decrease in the number of natural small water bodies has been observed. These objects fulfil many different and important functions in the environment and deserve conservation. Among the most important functions one should mention ecological function and retention, as well as raising the aesthetic and recreational values of landscape. Natural water bodies are significant in preserving biodiversity, which in case of small water bodies is often greater than in lakes and streams. They fulfil physio-coenotic function, making the element of ecological corridors, providing connections between ecosystems in the environment $[11,14,16,18]$. Thus more and more often they become protected by law. The Ramsar Convention on Wetlands [7] protects about 40 types of wetlands, including marshes, swamps, peats and water bodies of international significance as the habitat for waterfowl. Small water bodies are crucial in small retention of water $[4,8,9]$. In case of water bodies situated in the city agglomerations in anthropogenically transformed areas, aesthetic and - to some extent - recreational functions are becoming more and more important for the landscape $[10,16]$. Small water bodies are particularly susceptive on anthropogenic pressure of different kind $[2,3,14,16,17]$. Considering the above values and threats, small water bodies are particularly protected in many countries of Western Europe (Figs 1, 2).

Nowadays there are the possibilities of protecting small water bodies in Poland. According to the definition given by the Law on the Protection of Agricultural Land and Forest [19] a natural small water body is an area not exceeding 1 hectare, naturally filled with water, situated across fields, or forest area, where soil classification is inapplicable.

\footnotetext{
* AGH University of Science and Technology, Faculty of Mining Surveying and Environmental Engineering, Department of Management and Protection of Environment, Krakow, Poland

** The study was performed in the Department of Environmental Management and Protection and financed by research project no. 11.11.150.008
} 


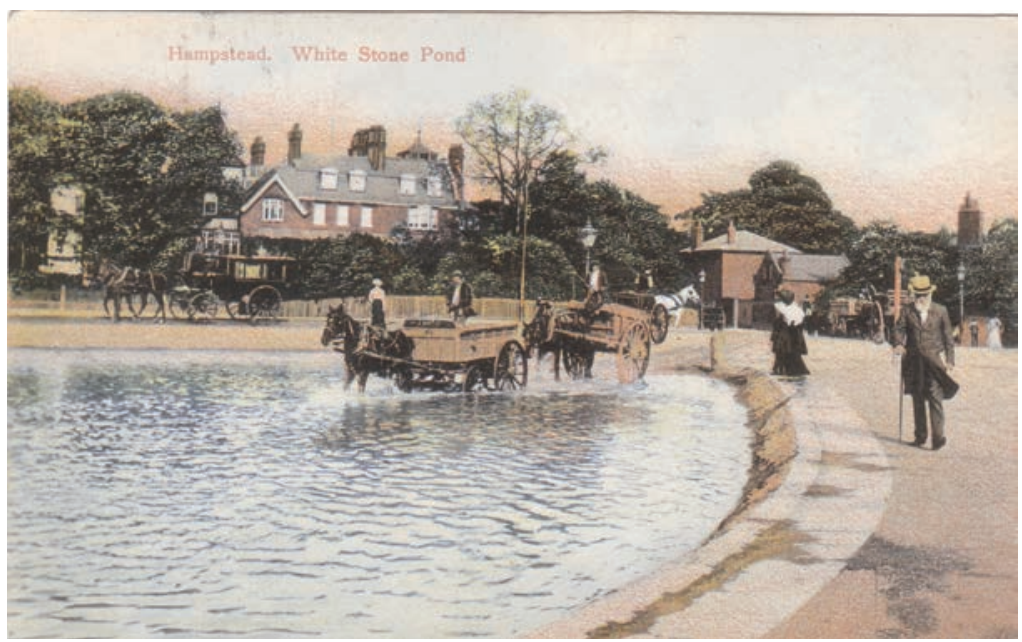

Fig. 1. London, district of Hampstead: archive photo of the Whitestone Pond a horse watering place (end of $19^{\text {th }}$ century)

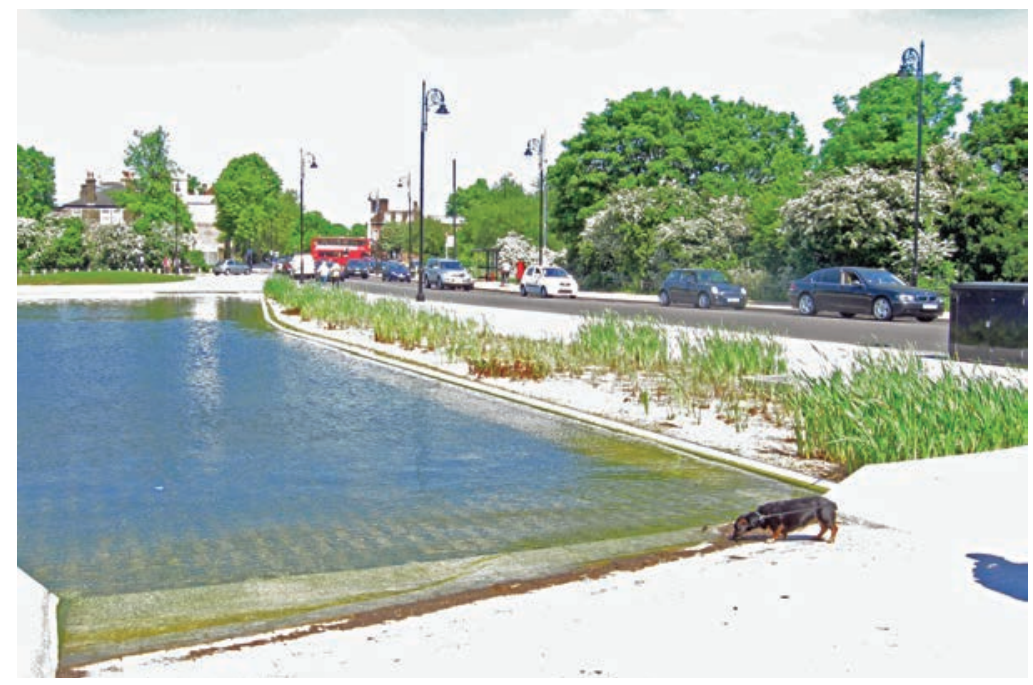

Fig. 2. London, district of Hampstead: a reconstructed horse watering place the Whitestone Pond (contemporary state 2012), the belt of wetland vegetation is seen and the shallow shore facilitating the access to water. (phot. Michael Lee)

The majority of available literature refers to the areas of north and central Poland $[3,4,13-16]$. However, there is very little literature data referring to the studies of small water bodies in the Krakow agglomeration and Małopolska region, because small natural water bodies are rare in the landscape of Southern Poland [among others: 1, 2, 10, 12]. 
The aim of the paper is the preliminary natural inventory of selected small water bodies within the Krakow agglomeration in the context of the assessment of their conservation possibilities.

\section{Material and Methods}

The study area included western part of the urban municipality of Krakow, i.e. the quarters of VII Zwierzyniec, IV Prądnik Biały and VIII Dębniki and the Zabierzów community.

The choice of the area was not accidental, for this fragment of Krakow agglomeration is characterized by great values of nature, landscape and recreation. At the same time, the area is subdued to great anthropogenic pressure, including constant expansion of urbanised and industrial areas.

Based on the previously performed water body inventory [1,12] seven sites were selected in the study area, according to the following criteria: origin, size, the characteristic of the surrounding area and the state of the site (Fig. 3).

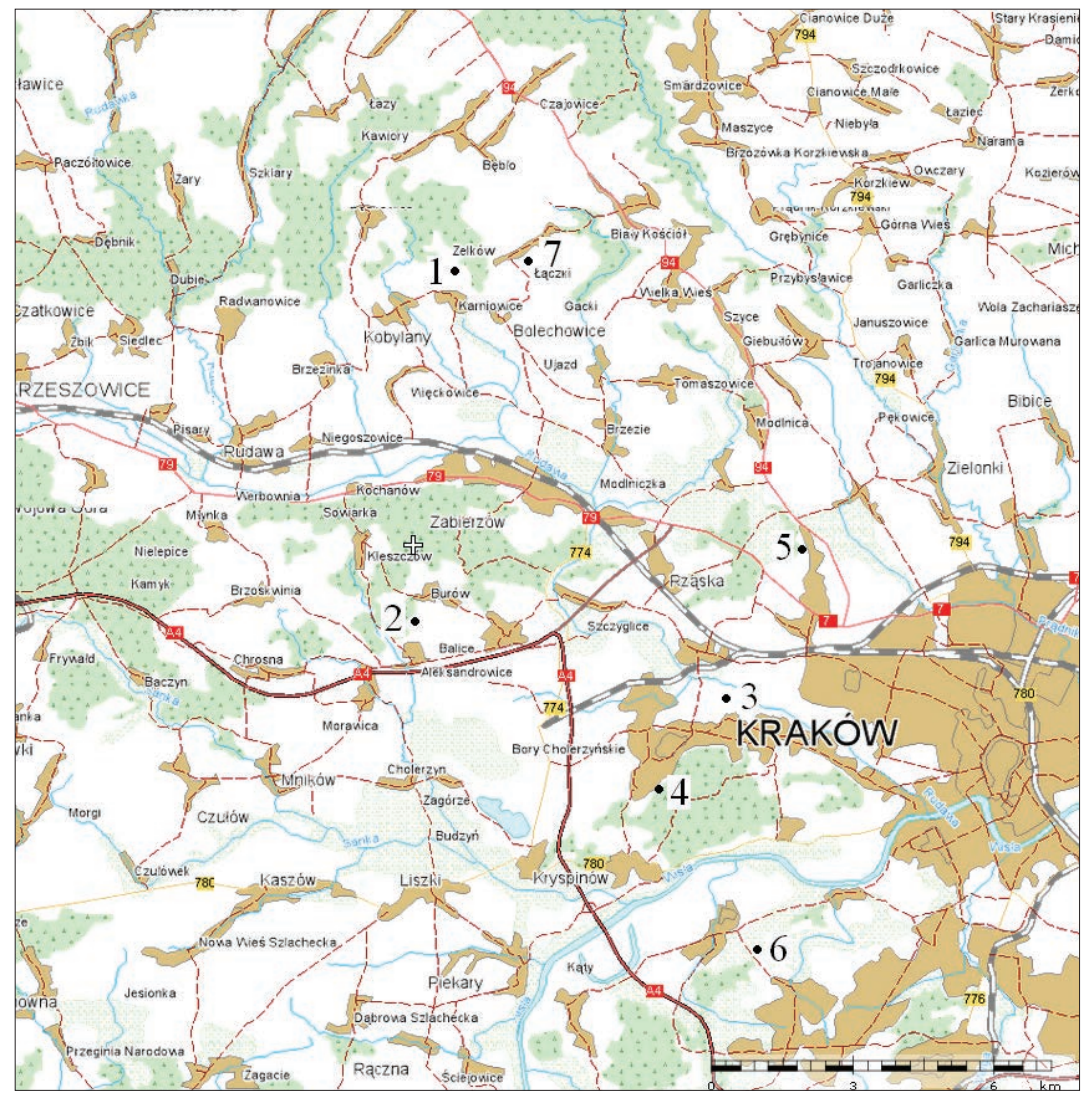

Fig. 3. Location of water bodies (1-7) 
Taking as the criterion the size, according to the classification by Klafs et al. [5] a simplified division was proposed: very small objects $(<0.125 \mathrm{ha})$, medium (0.125-0.5 ha) and large ones (0.5-1.0 ha).

According to the origin, the sites were classified as natural (old river beds, land slide structures, karst forms) and artificial ones.

The state of preservation was described as permanent/temporary.

The surrounding area was described as forest, agricultural land, urbanized area, while vegetation was characterised as emerged and shore vegetation.

The studies included the inventory of sites carried out according to established earlier criteria and chemical analyses of waters. The following parameters were analysed: $\mathrm{pH}$, specific conductivity, the content of macro-components in the ionic form: $\mathrm{Na}, \mathrm{K}, \mathrm{Ca}, \mathrm{Mg}, \mathrm{HCO}_{3}, \mathrm{Cl}, \mathrm{SO}_{4}$, and general mineralization (calculated as the sum of the analysed components). In 2012 the oxygen concentration and water temperature was measured and in previous years $-\mathrm{pH}$ and specific conductivity. The analyses were carried out in 2009, 2011, 2012 in the region of Krakow. The planned physical and chemical analyses of the waters of seven selected water bodies in subsequent years were not always possible to repeat, due to the lack of water, connected with the change of water conditions (drought, change of the conditions of filling the water body) the analysed cations, anions and physical conditions had the character of indicator analysis indicated in water monitoring.

The following methods of analysis were applied:

- pH electrometric - portable pH-meter HPP 350,

- electrolytic conductivity - portable conductometer Multi 350i by WTW and the oxygen content - using the electrode Con Ox,

- content of chlorides - tittering, argentometry according to PN-ISO 9297,

- content of sulphates - micro-process photometer LF 300,

- the content of magnesium, calcium, sodium and potassium - atomic spectrophotometer Hitachi Z 2000,

- alkalinity-tittering - in the relation to the indicators.

The description of the chemical composition of waters was based on the classification by Altowski and Szwiec [6]. General mineralization was understood as the sum of all the analysed cations and anions. The water was named, regarding the content of ions above $20 \% \mathrm{mval}$ in the relation to the sum of anions or cations. The water samples were analysed in the Laboratory of the Department of Environmental Management and Protection, Faculty of Mining Surveying and Environmental Engineering, AGH UST in Krakow.

\section{Results and Discussion}

Based on the established criteria the preliminary inventory of sites was carried out.

Site no. 1 Karniowice - the area of the water mirror of about 0.1 ha and depth below $1 \mathrm{~m}$ is located in the commune of Zabierzów, the locality of Góry Karniowskie, 
within the borders of the Landscape Park "Dolinki Krakowskie" (Fig. 4). This is a karst water body, formed by the collapse of karst Jurassic limestones, of the constant level of waters. The site is constantly filled with water, although the level of water and the area of the water mirror change temporarily. There is a $10-15 \mathrm{~m}$ wide belt of emerged hydrophytes, constantly expanding. It is represented by the common reed (Phragmitetum australis).

a)

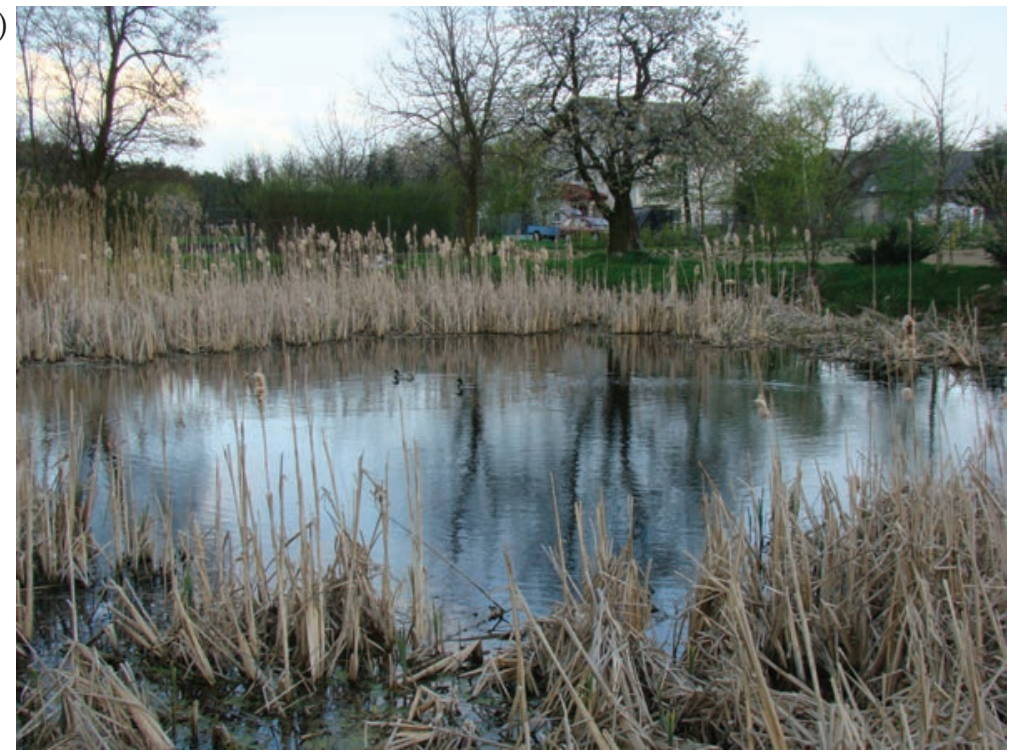

b)

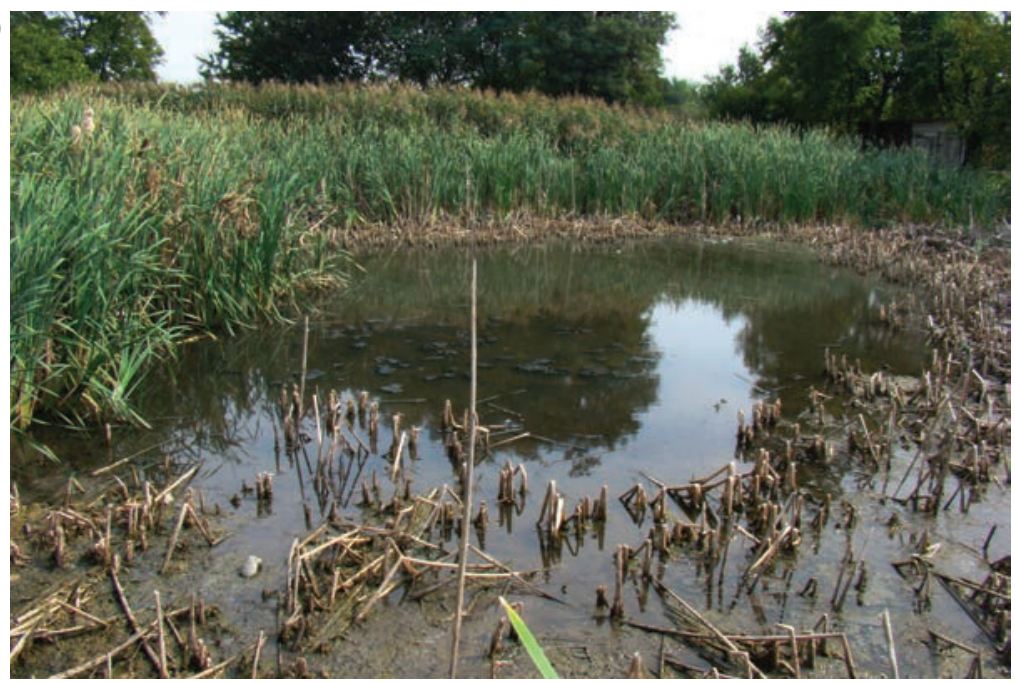

Fig. 4. Site no. 1 Karniowice: progressing process of overgrowing the water body with reed in 2009,2010 and 2012 
There are single trees on the shore, such as the black alder (Alnus glutinosaa). The surface of the area adherent to the water body is covered by: meadows from the north, the road from the west and from the east and south - family houses. In the northern part of the area surrounding the water body a melioration trench was made to drain the neighbouring meadows, which can change hydrological conditions of the area (lowering the level of the water mirror, surface flow). The site is highly devastated. The animals noted were mallards (Anas platyrhynchos) and a few species of frogs. Over 2009-2012 a significant diminishing of the area of the open water mirror was observed. The body of water also became shallower. The process of terrestrifying was visible mainly in the eastern part of the water body, covered by marsh vegetation. Around its borders and in the water there are numerous sources of pollution in the form of deposited rubbish as well as the released wastewater. The shores from the side of the road, as well as the residential building from the southern side are subsequently filled with debris and concrete slabs, which can lead to the liquidation of the object.

Site no. 2 Aleksandrowice - surface of the water mirror below 0.1 ha and depth below $50 \mathrm{~cm}$ is located in the area of the commune of Zabierzów in the locality of Aleksandrowice within the borders of the Tenczyn Landscape Park. It is a small water body of a flowing character, situated in the proximity of a small stream surrounded by forest. It has changeable level of waters as well as the area of the water mirror. In the shore zone there is a narrow belt (about $1 \mathrm{~m}$ ) of partially emerged plants. The shores of the water body and the adjacent area are covered with riparian forest with the high participation of the grey alder (Alnus incana) and black alder (Alnus glutinosa). In the understory the dominant species are wood anemone (Anemone nemorosa) and ruderal species, among other nettles (Urtica urens), covering the human-changed ground. From the western side in a distance of about $20 \mathrm{~m}$ there is a local road Aleksandrowice - Kochanów, posing threat for the fauna living in the water body. The presence of mallard and a few anuran species was confirmed.

Site no. 3 Rudawa - the area of the water mirror below 0.1 ha and depth below $50 \mathrm{~cm}$ is located within the commune of Krakow in the city area no. VII called Zwierzyniec, not covered by any form of legal protection (Fig. 5). It is an area subsidence with no drainage, of depth below $30 \mathrm{~cm}$ being an oxbow lake of the Rudawa River. It is characterized by changeable level of waters as well as the surface of the water mirror. The process of lowering the level of waters and diminishing of the water body was observed over the years 2009-2012. Emerging macrophytes are absent both in the marginal area as well as in the central part. There are single trees: grey alder Alnus incana and ruderal species such as nettles Urtica urens. The area adjacent to the bowl of the water body is covered with grasslands. There are no fish or amphibians, although still at the beginning of $21^{\text {st }}$ century anurans laying eggs were observed. From the southern side in the distance of about $50 \mathrm{~m}$ there is a local road: the Pylna street, and from the SW 
side in the proximity of the object there is a melioration ditch. The site is strongly devastated. In water and in the waterless part of the bowl there are numerous sources of pollution.

a)

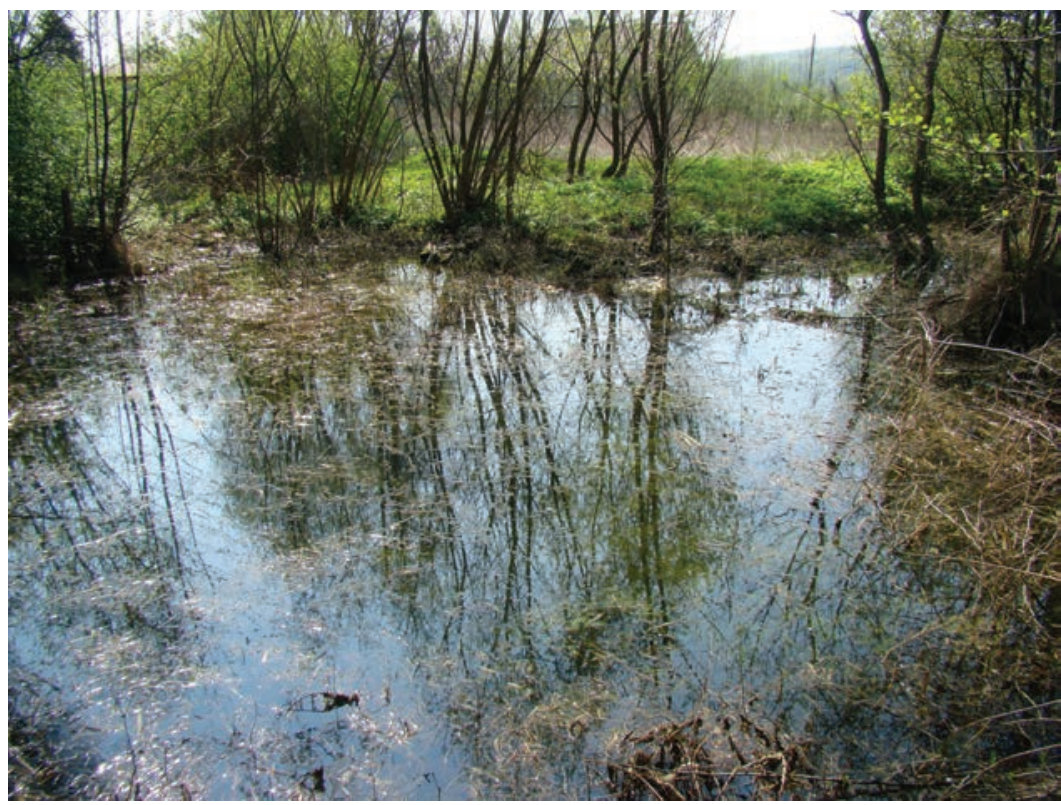

b)

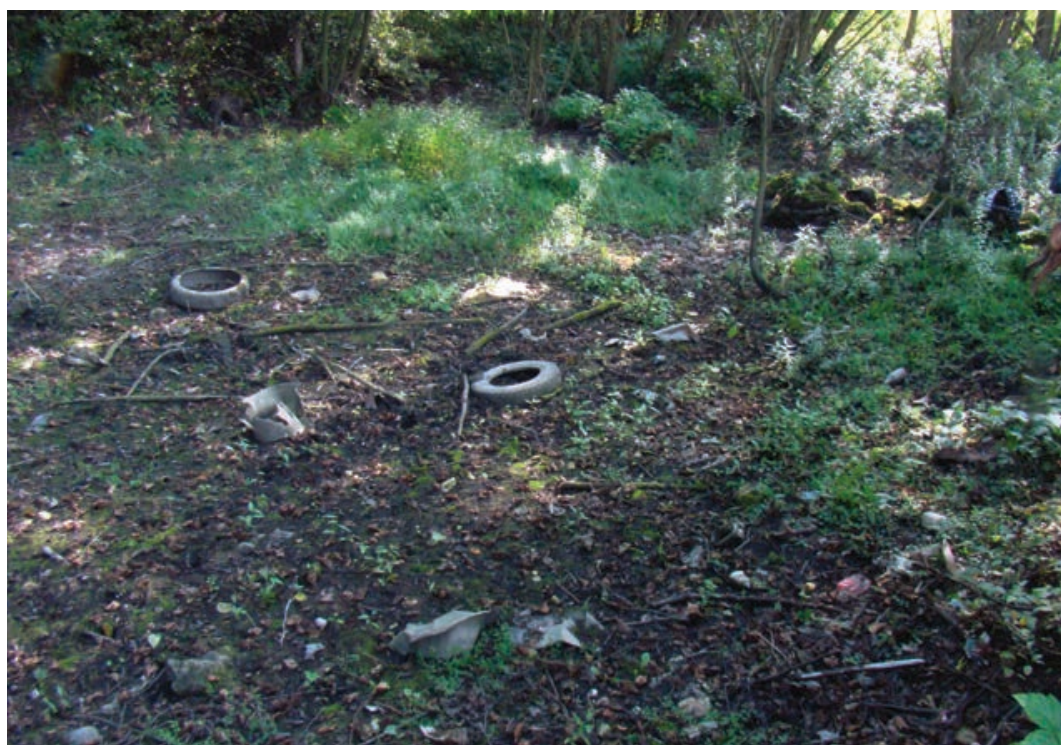

Fig. 5. Object no. 3 Rudawa: progressing process of the drainage of the water body in 2009, 2011 and 2012 
Site no. 4 Las Wolski - the area of the water mirror of about 0.1 ha and depth below $50 \mathrm{~cm}$ - is situated in the city of Krakow, the area no. VII called Zwierzyniec, in the area of Las Wolski within the boders of Bielańsko-Tyniecki Landscape Park. This is a small water body located on a small water stream, from the east and west it is limited by steep scarps, and from the north limited with the dyke. The object has a temporary character. It makes one of not numerous natural sources of drinking water for animals in Las Wolski. During the observations a trend of lowering the level of waters to their disappearance was noticed. There are no emerged vegetation, just in the biological lining there are trees with predominance of beech. No fish or amphibians were observed.

Site no. 5 Pasternik - water mirror area below 0.1 ha and depth below $50 \mathrm{~cm}$ - is located on the border of the communities of Krakow and Zabierzów in the area no. IV called Prądnik Biały, within the Tenczyn Landscape Park. This is a natural area subsidence with no drainage, okresowo wypełnione water. In the whole bowl of the water body there are partially emerged plants, represented mainly by genus Elodea Michx. The shores of the water as well as adjacent area is covered by riparian forest with the great participation of grey alder Alnus incana and willow. In the understory wood anemone Anemone nemorosa and ruderal species such as nettle Urtica urens dominate. In 2009 anuran eggs were observed. In the area adjacent to the object, in the distance of 50-100 $\mathrm{m}$ in SE direction there is a local road and one-family houses.

Site no. 6 Winnica is a water body of a medium size. The area of the water mirror about 0.5 ha is located in the area of Krakow, in the quarter no. VIII of Dębniki, within Bielańsko-Tyniecki Landscape Park (Fig. 6). This is an area subsidence with no drainage. Its shores are formed as scarps, being probably the remains of post-exploitation pit. The object is filled with water all the year round. In 2009-2012 a clear trend of the subsidence of water level and making the water body shallower was observed. The measurement of water depth was not measured. Irregular belt of emerged vegetation is $5-20 \mathrm{~m}$ wide. It is broad in the shore zone, mainly alongside the shores of NW part of the water body, gradually extending to a central part of the bowl of the lake. The vegetation is mainly common reed, represented by the association of Phragmitetum australis. In the vegetation of the shore, there are trees (among others the grey alder Alnus incana). The surface of the area adjacent to the bowl of the water body is covered by: riparian forests and wet meadows. The presence of mallard (Anas platyrhynchos) was noticed as well as dead anurans. From the northern side the site is neighbouring with the Factory of Bitumen Mass (Wytwórnia Mas Bitumicznych) - the industry belonging to the Region of Road Maintenance and Construction, and from the west - with the Winnicka street combining Kobierzyn with Tyniec. 
a)

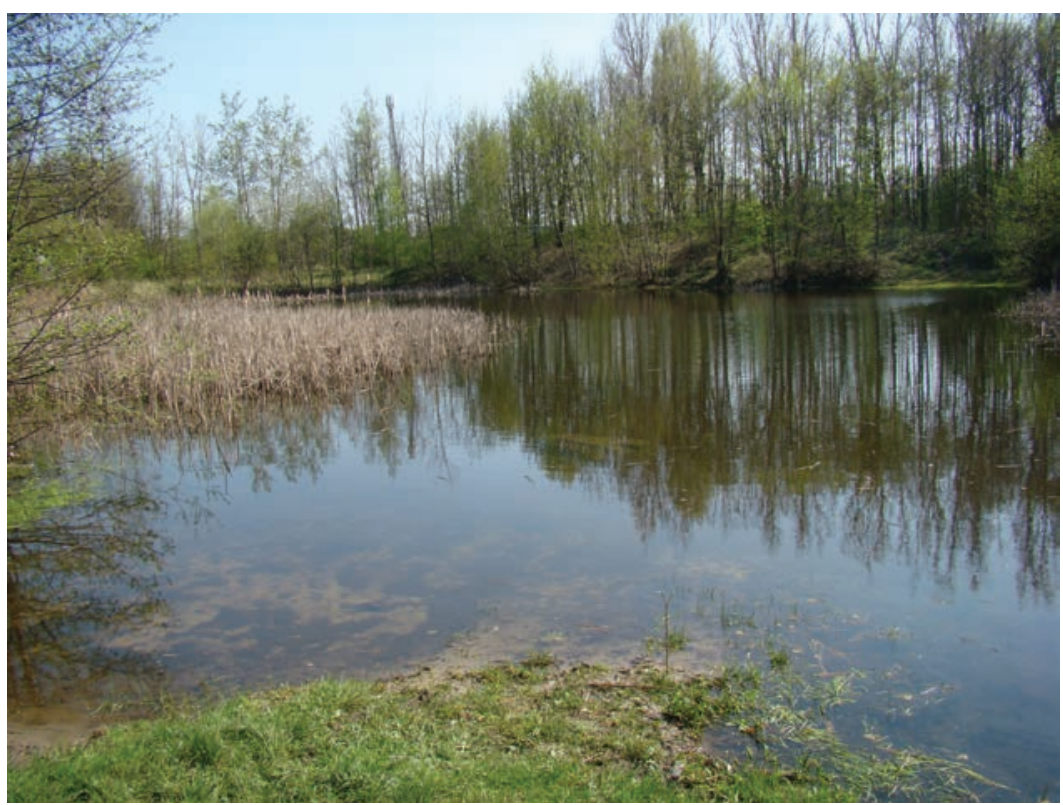

b)

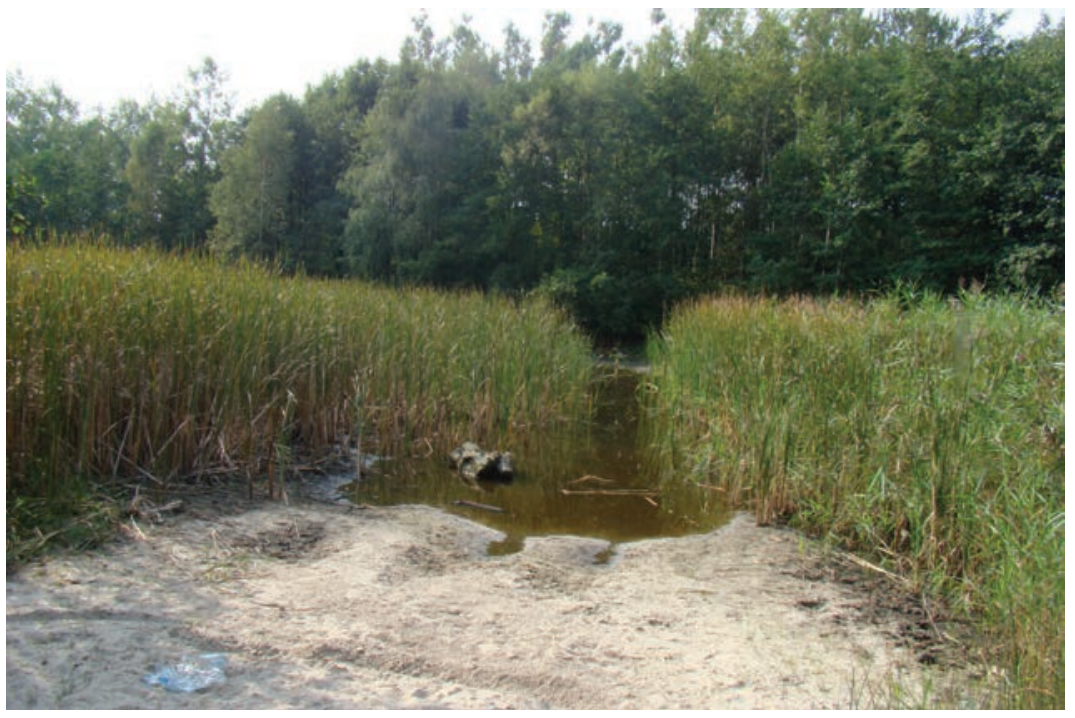

Fig. 6. Site no. 6 Winnica: progressing process of overgrowing the water body with reed in 2009,2011 and 2012

Site no. 7 Zelków is an object of a medium size - the surface of about 0.5 ha and depth not exceeding $100 \mathrm{~cm}$. It is located in the commune of Zabierzów within the Landscape Park "Dolinki Krakowskie". It is a natural karst water body, the shores of 
which are formed as scarps. It is located in the centre of the locality of Zelków in the proximity of road Zabierzów-Biały Kościół. Over 2009-2012 the constant level of waters as well as the area of the water mirror was found. In the shore zone in the NW and southern part of the water body there are emerged plants (yellow iris Iris pseudacorus and reed represented by the association of common reed Phragmitetum australis). The shore is overgrown by trees (larch, spruce, willow, and artificial plantings of ornamental shrubs). The occurrence of mallard (Anas platyrhynchos) and several anuran species was confirmed. The area adjacent to the water body is managed in a recreational way.

A brief characteristic of sites was presented in Table 1.

Table 1. The characteristic of water bodies

\begin{tabular}{|c|c|c|c|c|c|c|c|}
\hline \multirow{4}{*}{$\begin{array}{l}\text { Character- } \\
\text { istics }\end{array}$} & \multicolumn{7}{|c|}{ Water body number } \\
\hline & 1 & 2 & 3 & 4 & 5 & 6 & 7 \\
\hline & \multicolumn{7}{|c|}{ Location } \\
\hline & $\begin{array}{l}\text { Karniowice } \\
\text { N5009'22" } \\
\text { E19²46'36" }\end{array}$ & 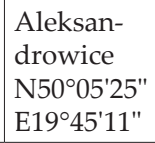 & $\begin{array}{l}\text { Rudawa } \\
\text { N5004'31" } \\
\text { E1951'21" }\end{array}$ & $\begin{array}{l}\text { Las Wolski } \\
\text { N5003'22" } \\
\text { E1950'21" }\end{array}$ & $\begin{array}{l}\text { Pasternik } \\
\text { N50 06'22" } \\
\text { E1952'38" }\end{array}$ & $\begin{array}{l}\text { Winnica } \\
\text { N5001'31" } \\
\text { E1952'02" }\end{array}$ & \begin{tabular}{|l|} 
Zelków \\
N5009'22" \\
E1947'48"
\end{tabular} \\
\hline Size & $S$ & $S$ & $S$ & $S$ & $S$ & $\mathrm{~L}$ & $\mathrm{M}$ \\
\hline Origin & $\mathrm{N}$ & $\mathrm{N}$ & $\mathrm{N}$ & $\mathrm{N}$ & $\mathrm{N}$ & A & $\mathrm{N}$ \\
\hline $\begin{array}{l}\text { Preservation } \\
\text { state }\end{array}$ & $P$ & $\mathrm{~T}$ & $\mathrm{~T}$ & $\mathrm{~T}$ & $\mathrm{~T}$ & $P$ & $\mathrm{P}$ \\
\hline $\begin{array}{l}\text { Character- } \\
\text { istics of the } \\
\text { adjacent area }\end{array}$ & $\mathrm{A} / \mathrm{U}$ & $\mathrm{F} / \mathrm{U}$ & F/A/U & F & $\mathrm{F}$ & $\mathrm{F} / \mathrm{U}$ & $\mathrm{U}$ \\
\hline
\end{tabular}

Explanations: size: S - small, M - medium, L - large; origin: N - natural, A - artificial; preservation state: $\mathrm{P}$ - permanent, $\mathrm{T}$ - temporary; characteristics of the adjacent area: $\mathrm{U}$ - urbanized, $\mathrm{F}-\mathrm{forest}, \mathrm{A}-$ agricultural

The paper presents the preliminary results of the hydro-chemical image presented for the selected seven water bodies in 2009-2012. The results of physical and chemical analyses were put in tables Tables $2-4$. The temperature of studied waters ranged from $17.6^{\circ} \mathrm{C}$ to $25^{\circ} \mathrm{C}$, which is related to the place of sampling (forest area, covered area, or the area exposed to sun). General mineralization is calculated as the sum of the determined macro-ingredients was $0.1-0.6 \mathrm{~g} / \mathrm{dm}^{3}$, on average $0.5 \mathrm{~g} / \mathrm{dm}^{3}$, characterizes these waters as fresh. The $\mathrm{pH}$ of waters ranged from 7.0 to 8.5; usually it was typical for slightly alkaline waters, which should be associated with the presence of carbonates. The differences in chemical composition connected with the place of sampling are small. They indicate certain connection with the lithological character of the ground, built of limestone and marl or loess cover as well as silt Miocene formations. Thus the majority of examined waters can be called hydrocarbonate-calcium-magnesium, unfortunately with the participation of sulphate ion if one accepts as main components ions occurring in the content of $20 \% \pm 3 \%$. 


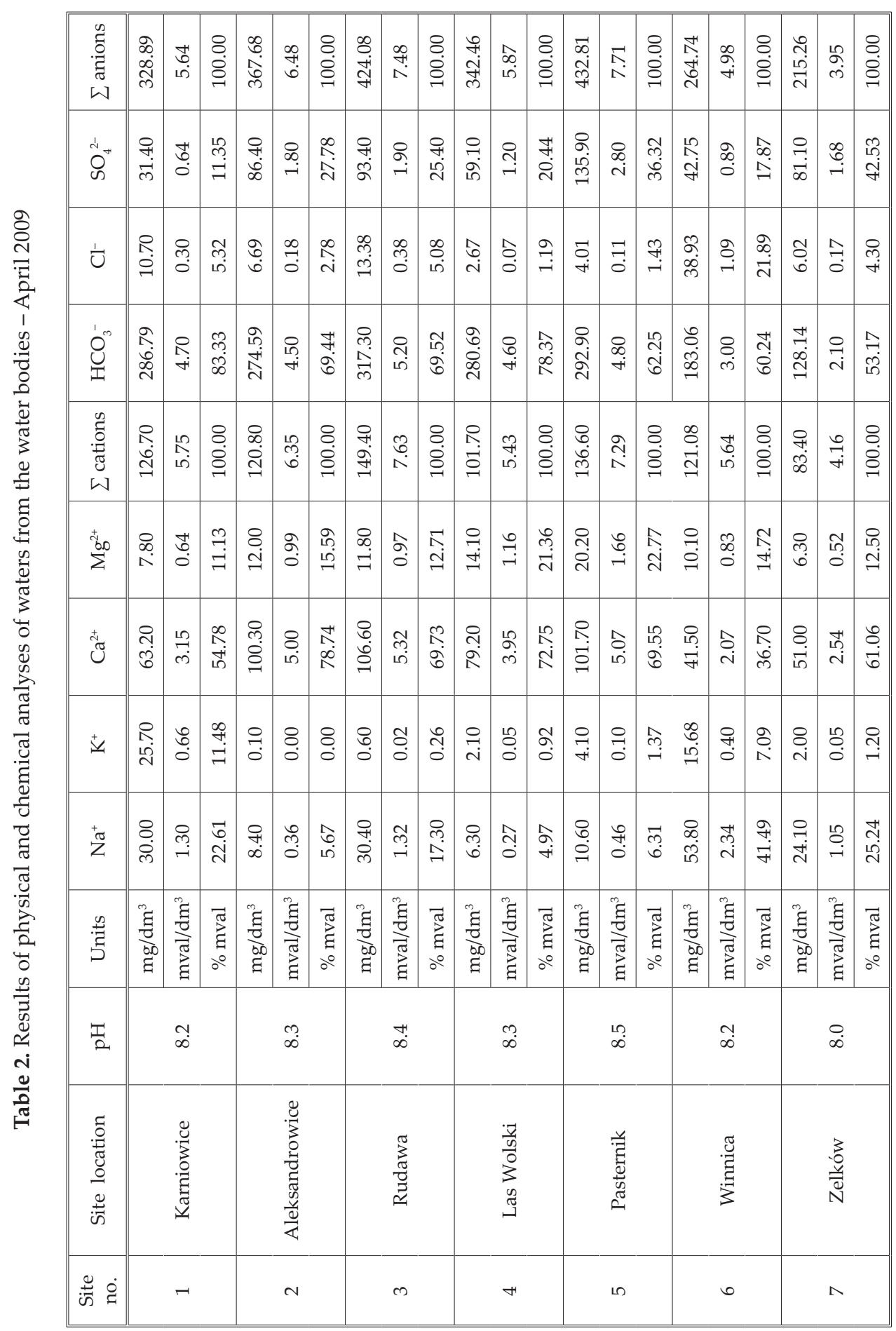




\begin{tabular}{|c|c|c|c|c|c|c|c|c|c|c|c|c|c|c|c|c|c|c|c|c|c|}
\hline 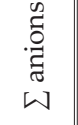 & 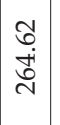 & $\begin{array}{l}\hat{b} \\
\stackrel{+}{+}\end{array}$ & $\begin{array}{l}8 \\
\stackrel{0}{0} \\
\stackrel{0}{2}\end{array}$ & 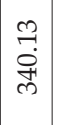 & 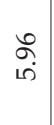 & $\begin{array}{l}8 \\
\dot{8} \\
\dot{9}\end{array}$ & $\begin{array}{l}2 \\
\curvearrowright \\
\infty \\
\infty \\
\infty\end{array}$ & $\tilde{\sigma}$ & \& & $\begin{array}{l}\infty \\
\infty \\
\stackrel{+}{+1} \\
\text { ले }\end{array}$ & $\underset{\mathrm{d}}{\mathrm{D}}$ & $\begin{array}{l}8 \\
8 \\
8\end{array}$ & $\begin{array}{l}R \\
\vdots \\
\infty\end{array}$ & $\stackrel{\stackrel{\leftrightarrow}{\rightarrow}}{\rightarrow}$ & $\begin{array}{l}8 \\
\ddot{8} \\
\dot{8}\end{array}$ & 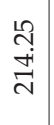 & $\begin{array}{l}\tilde{\sigma} \\
\dot{\rho}\end{array}$ & $\begin{array}{l}8 \\
\stackrel{8}{8} \\
8\end{array}$ & $\begin{array}{l}\stackrel{\infty}{\sim} \\
\infty \\
\stackrel{0}{\sim} \\
\stackrel{0}{N}\end{array}$ & 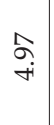 & $\begin{array}{l}8 \\
\stackrel{8}{8} \\
\stackrel{0}{0}\end{array}$ \\
\hline$\stackrel{\dot{I}}{+}^{+}$ & $\begin{array}{l}\Re \\
\dot{m}\end{array}$ & $\begin{array}{l}\mathscr{0} \\
\stackrel{0}{0}\end{array}$ & $\stackrel{\stackrel{M}{\rightleftarrows}}{\underset{\sim}{ \pm}}$ & $\begin{array}{c}\hat{O} \\
\text { İ } \\
\text { f }\end{array}$ & $\begin{array}{l}\hat{\infty} \\
\stackrel{0}{0}\end{array}$ & $\begin{array}{l}8 \\
\stackrel{0}{+} \\
\dot{+}\end{array}$ & $\begin{array}{l}0 \\
\stackrel{2}{0} \\
-1\end{array}$ & 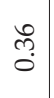 & $\begin{array}{l}\text { กิ } \\
\text { ம் }\end{array}$ & $\begin{array}{l}\text { J゙ } \\
\text { নू }\end{array}$ & $\stackrel{\Omega}{-}$ & $\begin{array}{l}\text { ณก } \\
\text { ลิ }\end{array}$ & $\begin{array}{l}\vec{\infty} \\
\text { ले } \\
\text { ले }\end{array}$ & $\begin{array}{l}\infty \\
0 \\
0\end{array}$ & $\begin{array}{l}\text { ठு } \\
\stackrel{8}{+}\end{array}$ & 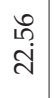 & 苗 & 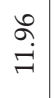 & $\begin{array}{l}\stackrel{0}{0} \\
\stackrel{2}{2}\end{array}$ & ભे & $\begin{array}{l}\stackrel{\infty}{\infty} \\
\stackrel{\infty}{\wedge}\end{array}$ \\
\hline$\dot{U}$ & $\begin{array}{l}0 \\
\text { లై } \\
\text { }\end{array}$ & 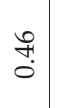 & $\begin{array}{l}\stackrel{\llcorner}{\infty} \\
\infty \\
\sigma\end{array}$ & $\stackrel{\widehat{c}}{\stackrel{\rho}{\sigma}}$ & भ़े & $\begin{array}{l}\tilde{N} \\
\infty\end{array}$ & $\begin{array}{l}\stackrel{7}{\rightrightarrows} \\
\vec{F}\end{array}$ & $\begin{array}{l}\stackrel{0}{\sim} \\
\stackrel{-}{2}\end{array}$ & $\stackrel{\hat{~}}{\mathrm{o}}$ & 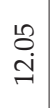 & ڤై & $\begin{array}{l}\stackrel{+}{+} \\
\dot{+}\end{array}$ & $\begin{array}{l}\dot{\partial} \\
\dot{i}\end{array}$ & \begin{tabular}{l}
$\mathscr{0}$ \\
\hdashline \\
0
\end{tabular} & $\underset{\mathscr{H}}{\stackrel{8}{+}}$ & $\begin{array}{l}\text { बे } \\
\text { dे }\end{array}$ & $\begin{array}{l}0 \\
\stackrel{0}{0}\end{array}$ & $\begin{array}{l}\text { ले. } \\
\text { बे }\end{array}$ & $\begin{array}{l}\vec{\sigma} \\
b \\
b\end{array}$ & 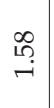 & શે \\
\hline 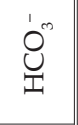 & 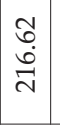 & $\begin{array}{l}\stackrel{\llcorner}{10} \\
\stackrel{n}{n}\end{array}$ & 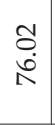 & 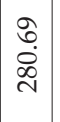 & $\begin{array}{l}\stackrel{8}{\bullet} \\
+\end{array}$ & 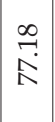 & $\begin{array}{l}\overrightarrow{1} \\
\text { हें } \\
\text { ले }\end{array}$ & $\begin{array}{l}\text { P! } \\
\text { in }\end{array}$ & $\begin{array}{l}8 \\
\infty \\
\infty \\
\infty\end{array}$ & 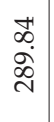 & 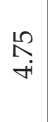 & \begin{tabular}{l}
0 \\
\multirow{0}{0}{} \\
$\hat{\sigma}$
\end{tabular} & $\begin{array}{l}\hat{N} \\
\stackrel{9}{+}\end{array}$ & $\begin{array}{l}\mathfrak{L} \\
\stackrel{2}{0} \\
0\end{array}$ & $\begin{array}{l}\stackrel{3}{ } \\
\text { in } \\
\text { in }\end{array}$ & 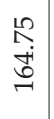 & i & $\begin{array}{l}R \\
\infty \\
\infty\end{array}$ & $\begin{array}{l}0 \\
\infty \\
\infty \\
\infty \\
-1\end{array}$ & $\underset{\infty}{\stackrel{8}{ }}$ & $\begin{array}{l}0 \\
\text { ని } \\
8\end{array}$ \\
\hline $\begin{array}{c}0 \\
0 \\
.0 \\
0 \\
0 \\
\omega\end{array}$ & $\begin{array}{l}8 \\
\infty \\
\infty \\
\infty\end{array}$ & $\underset{+}{\stackrel{+}{+}}$ & \begin{tabular}{l}
8 \\
$\stackrel{8}{0}$ \\
\hdashline
\end{tabular} & $\mid \begin{array}{l}\text { 유 } \\
\infty \\
\stackrel{0}{=}\end{array}$ & $\stackrel{\infty}{\underset{6}{0}}$ & $\begin{array}{l}8 \\
\dot{8} \\
\dot{8}\end{array}$ & $\begin{array}{l}9 \\
9 \\
\infty \\
0 \\
\\
\end{array}$ & 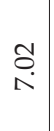 & 8 & $\begin{array}{l}\stackrel{\overbrace{}}{n} \\
\vec{m}\end{array}$ & $\underset{\sim}{8}$ & $\begin{array}{l}8 \\
8 \\
8 \\
8\end{array}$ & 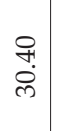 & 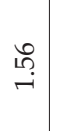 & \begin{tabular}{l}
8 \\
$\stackrel{8}{8}$ \\
\hdashline
\end{tabular} & $\begin{array}{l}8 \\
\stackrel{0}{+} \\
\stackrel{+}{*}\end{array}$ & $\begin{array}{l}0 \\
\stackrel{1}{n}\end{array}$ & $\begin{array}{l}8 \\
\dot{8} \\
\stackrel{-}{0}\end{array}$ & \begin{tabular}{l}
$\infty$ \\
$\infty$ \\
$\dot{0}$ \\
\hdashline
\end{tabular} & $\begin{array}{l}\infty \\
\stackrel{\infty}{+} \\
+\end{array}$ & $\begin{array}{l}8 \\
\stackrel{8}{8} \\
\stackrel{0}{0}\end{array}$ \\
\hline$\sum_{\Sigma}^{+50}$ & $\begin{array}{l}\stackrel{8}{0} \\
\stackrel{1}{0}\end{array}$ & $\begin{array}{l}\hat{\mho} \\
\dot{0}\end{array}$ & 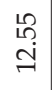 & $\begin{array}{l}0 \\
0 \\
0 \\
0\end{array}$ & $\begin{array}{c}\hat{\infty} \\
\stackrel{\infty}{\circ}\end{array}$ & \begin{tabular}{|l|}
$\infty$ \\
$\dot{+}$ \\
$\dot{+}$
\end{tabular} & $\begin{array}{l}\infty \\
\infty \\
\mathfrak{I}\end{array} \mid$ & 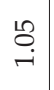 & ๖̊ & $\begin{array}{l}\stackrel{ }{+} \\
\stackrel{-}{n}\end{array}$ & $\stackrel{\mathscr{P}}{\rightarrow}$ & $\begin{array}{l}\stackrel{?}{:} \\
\stackrel{\text { N }}{0}\end{array}$ & $\begin{array}{l}\infty \\
\infty \\
\dot{\infty}\end{array}$ & $\vec{m}$ & 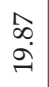 & $\underset{6}{8}$ & 导 & $\begin{array}{l}\ddot{8} \\
\stackrel{9}{-}\end{array}$ & 웜 & $\underset{0}{0}$ & $\begin{array}{l}R \\
\stackrel{R}{\rightarrow}\end{array}$ \\
\hline$\stackrel{\sim}{\mathcal{U}}$ & 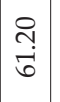 & $\begin{array}{l}\qquad 0 \\
\ddot{\infty}\end{array}$ & $\begin{array}{l}\stackrel{+}{ث} \\
\vec{\sigma}\end{array}$ & $\begin{array}{l}\infty \\
\infty \\
\infty \\
\infty\end{array}$ & $\stackrel{\curvearrowright}{\not}$ & \begin{tabular}{l}
$\hat{A}$ \\
\multirow{2}{*}{}
\end{tabular} & \begin{tabular}{l} 
त̂ \\
\multirow{+}{*}{}
\end{tabular} & $\stackrel{R}{\stackrel{R}{+}}$ & 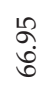 & 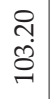 & $\begin{array}{l}\stackrel{2}{\circ} \\
\stackrel{10}{0}\end{array}$ & 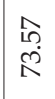 & $\begin{array}{l}8 \\
\stackrel{0}{0} \\
\stackrel{2}{2}\end{array}$ & 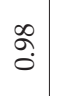 & $\begin{array}{l}\infty \\
\infty \\
\text { త్ }\end{array}$ & $\begin{array}{l}\text { तิ } \\
\text { in }\end{array}$ & $\begin{array}{l}\stackrel{8}{\bullet} \\
\stackrel{i}{i}\end{array}$ & 웅 & $\begin{array}{l}\text { +̣ } \\
\text { ते }\end{array}$ & $\stackrel{\text { ले }}{\rightarrow}$ & 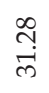 \\
\hline \pm & $\begin{array}{l}\stackrel{\text { I }}{+} \\
\text { J }\end{array}$ & $\begin{array}{l}\text { तु } \\
0\end{array}$ & 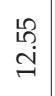 & $\begin{array}{l}\infty \\
\stackrel{\infty}{0} \\
\stackrel{0}{2}\end{array}$ & $\begin{array}{c}\mathrm{o} \\
\stackrel{0}{0}\end{array}$ & 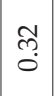 & $\begin{array}{l}9 \\
\text { in } \\
\text { ni }\end{array}$ & $\stackrel{ت}{\stackrel{H}{0}}$ & $\stackrel{\sigma}{\sigma}$ & $\begin{array}{l}8 \\
\text { i }\end{array}$ & $\begin{array}{l}\qquad 0 \\
0 \\
0\end{array}$ & ్ㅗㅇ & 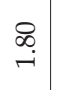 & $\begin{array}{l}\dot{J} \\
0 \\
0\end{array}$ & $\begin{array}{l}\stackrel{\circ}{\circ} \\
\text { in }\end{array}$ & $\begin{array}{l}\stackrel{8}{0} \\
\stackrel{i}{ }\end{array}$ & $\begin{array}{l}0 \\
0 \\
0\end{array}$ & $\stackrel{\infty}{\infty}$ & 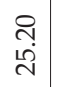 & $\underset{0}{\overparen{0}}$ & $\begin{array}{l}\vec{b} \\
\dot{I}\end{array}$ \\
\hline 节 & 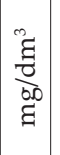 & $\begin{array}{l}\stackrel{n}{\Xi} \\
\frac{0}{0} \\
\vec{\pi} \\
\vec{\Xi}\end{array}$ & 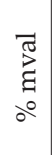 & $\left|\begin{array}{l}n \\
\Xi \\
0 \\
00 \\
\Xi \\
E\end{array}\right|$ & 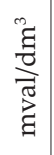 & $\begin{array}{c}\widetilde{J} \\
\stackrel{\Xi}{\Xi} \\
0\end{array}$ & $\left|\begin{array}{c}0 \\
\tilde{Z} \\
\frac{0}{0.0} \\
\Xi \\
Z\end{array}\right|$ & 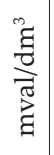 & 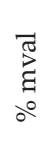 & 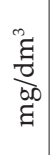 & 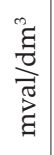 & 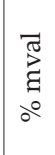 & 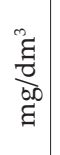 & $\begin{array}{l}\stackrel{n}{\Xi} \\
\frac{0}{0} \\
\vec{\pi} \\
\stackrel{\Xi}{\Xi}\end{array}$ & 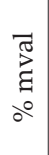 & 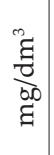 & 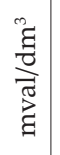 & $\begin{array}{c}\vec{c} \\
\stackrel{\vec{a}}{a} \\
0^{\circ}\end{array}$ & $\begin{array}{l}\stackrel{\infty}{E} \\
\frac{0}{0.0} \\
\stackrel{\Xi}{E}\end{array}$ & 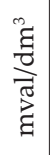 & 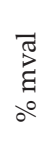 \\
\hline 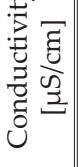 & & $\stackrel{\infty}{\not}$ & & & 斗 & & & $\stackrel{\infty}{\&}$ & & & 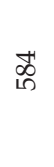 & & & 웅 & & & సี & & & $\stackrel{\infty}{\underset{f}{f}}$ & \\
\hline$\underset{2}{I}$ & & $\stackrel{\Re}{\wedge}$ & & & $\stackrel{\curvearrowright}{\wedge}$ & & & $\stackrel{10}{\sim}$ & & & $\stackrel{\sharp}{\Lambda}$ & & & $\stackrel{\circ}{\circ}$ & & & $\stackrel{\sim}{\infty}$ & & & $\stackrel{\circ}{\wedge}$ & \\
\hline 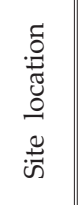 & & 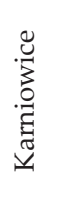 & & & 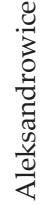 & & & $\begin{array}{l}\frac{\pi}{3} \\
\frac{\pi}{0} \\
\frac{1}{2}\end{array}$ & & & 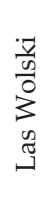 & & & 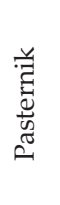 & & & 节 & & & $\begin{array}{l}3 \\
\text { 号 } \\
\text { " } \\
\text { N }\end{array}$ & \\
\hline 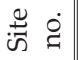 & & - & & & $N$ & & & $m$ & & & 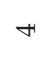 & & & 10 & & & 0 & & & $\wedge$ & \\
\hline
\end{tabular}


In water bodies Zelków and Winnica the waters showed the content of chlorines above $20 \%$ of gram-equivallents. In further studies one should explain the origin of chlorines and extending the range of the analyses of the compounds of nitrogen and phosphorus. In 2012 the studies were supplemented with the determinations of oxygen in waters. Low contents of oxygen and the $\mathrm{pH}$ can indicate very advanced eutrophication in which the processes of decomposition strongly dominate over the production processes. High content of water-dissolved oxygen, exceeding 100\% probably results from the activity of photosynthesising organisms and can be connected with progressing eutrophication process.

Table 4. Results of selected analyses of waters from water bodies - September 2012

\begin{tabular}{|c|c|c|c|c|c|c|}
\hline \multirow{2}{*}{$\begin{array}{l}\text { Site } \\
\text { no. }\end{array}$} & \multirow{2}{*}{ Site location } & \multirow{2}{*}[\mathrm{pH}]{} & Conductivity & Temperature & Oxygen & Oxygen \\
\hline & & & {$[\mu S / \mathrm{cm}]$} & {$\left[{ }^{\circ} \mathrm{C}\right]$} & {$\left[\mathrm{mg} / \mathrm{dm}^{3}\right]$} & {$[\%]$} \\
\hline 1 & Karniowice & 7.7 & 1022 & 25.0 & 3.12 & 27.4 \\
\hline 2 & Aleksandrowice* & - & - & - & - & - \\
\hline 3 & Rudawa* & - & - & - & - & - \\
\hline 4 & Las Wolski & 7.3 & 356 & 17.8 & 0.68 & 6.8 \\
\hline 5 & Pasternik* & - & - & - & - & - \\
\hline 6 & Winnica & 7.2 & 373 & 17.6 & 7.89 & 73.4 \\
\hline 7 & Zelków & 8.5 & 499 & 20.0 & 11.94 & 130.0 \\
\hline
\end{tabular}

* The pond was dry.

Lithology of the ground and hydrological character of the water body (connected or not connected with streams) significantly influence chemical composition of waters. Climatic conditions, through evaporation or atmospheric precipitation also influence chemical composition by making higher or lower concentrations of the analysed components. The influence of possible anthropogenic factors on the formation of chemical composition of waters was analysed based on the description and differentiation of natural conditions of water bodies. Sometimes in their proximity there was rubbish or it was suspected that municipal wastewaters or industrial wastes were discharged.

\section{Conclusions}

1. Among seven inventoried small water bodies six sites are of natural origin,

2. Six objects make very small water bodies of the surface not exceeding 0.125 ha, which makes them most threatened by degradation or liquidation; in their case protective measures are necessary. 
3. Five small water bodies are localised within urbanized areas of differentiated infrastructure: Zelków (detached family houses), Winnica (industrial infrastructure and agricultural land). Two objects (Las Wolski and Pasternik) are in-forest small water bodies.

4. In all the sites (except for Zelków) the lowering of the level of the water mirror was observed and/or the expansion of emerged vegetation, which leads to the disappearance of the objects

5. All the sites, except for Rudawa are situated within the borders of landscape parks, which gives chance for their protection

6. The studies should be extended to the sites situated within the administrative borders of Krakow, as exposed to maximal, multifaceted anthropogenic pressure.

7. Detail studies of the quality of waters from the studied water bodies should be extended to chemical analyses from the content of biogenic compounds.

8. Small water bodies play an important role in the preservation and the enrichment of biodiversity. They often make important water reservoirs, as well as increase the recreational and landscape values of the region. Thus it is necessary to make their detail inventory and take them under protection.

\section{References}

[1] Bedla D.: Rola naturalnych małych zbiorników wodnych, tzw. oczek wodnych, w zwiększeniu bioróżnorodności środowiska przyrodniczego na przykładzie wybranych gmin województwa małopolskiego. Wydział Geodezji Górniczej i Inżynierii Środowiska AGH, Kraków 2005 [unpubl.].

[2] Bedla D., Petryk A.: Funkcjonowanie wyrobiskowych zbiorników wody w Przegini pod Krakowem. Inżynieria Ekologiczna, nr 22, 2010, pp. 83-89.

[3] Bosiacka B., Pieńkowski P.: Analiza przekształceń oczek wodnych oraz ocena walorów przyrodniczych śródpolnych zbiorników w centralnej części Równiny Nowogardzkiej. Woda -Środowisko - Obszary Wiejskie, t. 4, z. 2a (11), 2004, pp. 335-349.

[4] Fiedler M., Szafrański C., Bykowski J.: Możliwości zwiększenia retencji oczek wodnych w zdrenowanej mikrozlewni rolniczej. Ochrona i Rekultywacja Gruntów. Materiały Konferencji Naukowo-Technicznej, Baranów Sandomierski 14-16.06.2000, [in:] Inżynieria Ekologiczna, nr 1, 2000, pp. 120-128.

[5] Klafs G., Jeschke L., Schmidt H.: Genese und Systematyk wasserführender Ackerhohlformen in den Nordbezierken der DDR. Archiv für Naturschutz und Landschaftsforschung, vol. 13, 4, 1973, pp. 287-302.

[6] Kleczkowski A.: Hydrogeologia ziem wokót Polski. Wydawnictwa Geologiczne, Warszawa 1979. 
[7] Konwencja o obszarach wodno-błotnych majacych znaczenie międzynarodowe, zwłaszcza jako środowisko życiowe ptactwa wodnego, sporządzona w Ramsarze dnia 2 lutego 1971 r. Dz. U. 1978, nr 7, poz. 24.

[8] Mioduszewski W.: Mała retencja w lasach elementem kształtowania i ochrony zasobów wodnych. Studia i Materiały Centrum Edukacji PrzyrodniczoLeśnej, r. 10, z. 2 (18), 2008, pp. 33-48.

[9] MioduszewskiW.: Rolamałejretencjinaterenachrolnych.IV Międzynarodowa Konferencja Województwa Małopolskiego „Scalanie gruntów instrumentem ochrony przed powodzią", Kraków 30 września 2010 r.

[10] Nowacka-Rejzner U.: Stawy i tereny podmokłe w obszarze miasta. Czasopismo Techniczne z. 23. Architektura z. 7-A, 2007, pp. 127-134.

[11] Ozga M.: Rola małych zbiorników wodnych w ochronie bioróżnorodności. Parki Narodowe i Rezerwaty Przyrody, t. 29 (3), 2010, pp. 117-124.

[12] Panek E., Bedla D.: Ecological and Landscape Valuation of Small Water Bodies in the Selected Municipalities of the Małopolska Province. Geomatics and Environmental Engineering, vol. 2, no. 4, 2008, pp. 59-60.

[13] Pieńkowski P., Kupiec M.: Proces zarastania jeziora Świdwie i zmiany w użytkowaniu jego otoczenia od początku XIX do końca XX wieku. Zeszyty Naukowe. Inżynieria Środowiska / Politechnika Zielonogórska, nr 125, 2001, pp. 265 277.

[14] Pieńkowski P.: Analiza rozmieszczenia oczek wodnych oraz zmian w ich wystepowaniu na obszarze Polski pótnocno-zachodniej. Akademia Rolnicza, Szczecin 2003.

[15] Pieńkowski P., Podlasiński M., Karaś K.: Próba oceny wpływu położenia oczek wodnych w rzeźbie terenu na tempo ich zanikania. Woda - Środowisko Obszary Wiejskie, t. 10, z. 1 (29), 2010, pp. 167-174.

[16] Piesik J.: Małe zbiorniki wodne w krajobrazie Szczecina. Nauka Przyroda Technologie, t. 3, z. 1, 2009, pp. 1-10.

[17] Surmacki A.: Zagrożenia małych zbiorników śródpolnych na Pomorzu Zachodnim. Chrońmy Przyrodę Ojczysta, r. 54, z. 6, 1998, pp. 61-69.

[18] Symonides E.: Znaczenie powiąań ekologicznych w krajobrazie rolniczym. Woda - Środowisko - Obszary Wiejskie, t. 10, z. 4 (32), 2010, pp. 249-263.

[19] Ustawa z dnia 3 lutego 1995 r. o ochronie gruntów rolnych i leśnych. Dz. U. nr 16, poz. 78 [Law of $3^{\text {rd }}$ February 1995 on the Protection of Agricultural Land and Forests. Journal of Laws No. 16, item 78]. 